\title{
„Próżny teatr życia”. Do Jana Libiniusza. Usprawiedliwienie swej samotności (Oda IV. 12) Macieja Kazimierza Sarbiewskiego
}

\author{
Anna Al-Araj \\ https://orcid.org/0000-0002-8837-1468
}

Celem niniejszego artykułu jest przedstawienie zapatrywań Macieja Kazimierza Sarbiewskiego na wybrane kwestie z zakresu poetyki oraz interpretacja - wzbogacona o inne konteksty (Horacy, Jan Kochanowski) - jego Ody IV. 12 Do Jana Libiniusza. Usprawiedliwienie swej samotności. Rozważania poparte zostały odwołaniami do liryków i traktatów teoretycznych jezuity, cenną podbudowę stanowią ponadto rozprawy dotyczące twórczości sarmackiego Horacjusza autorstwa m.in. Andrzeja Borowskiego, Piotra Urbańskiego czy Elwiry Buszewicz. Artykuł składa się z dwóch zasadniczych części, z których pierwsza poświęcona jest poetyce sformułowanej Sarbiewskiego. Autorka przybliża w niej idee myśliciela dotyczące roli poety, hierarchii sztuk oraz funkcji zabiegu alegoryzacji i jego związku z koncepcją fabulosa theologia. W kolejnej części zwraca się uwagę na obecność motywów ignacjańskich w lirykach jezuity powstałych po 1625 roku. Nawiązania do doktryny zakonu św. Ignacego Loyoli w silnym stopniu naznaczają także tkankę $O d y$ IV. 12, równie istotnymi kontekstami są ponadto topos theatrum mundi oraz dorobek literacki Horacego (zwłaszcza Carm. III. 1). Rozważania zostają zwieńczone tezą o spójności wyłożonych w rozprawach teoretycznych idei z wydźwiękiem „późnych” utworów Sarbiewskiego.

Słowa kluczowe: Maciej Kazimierz Sarbiewski, oda, topos theatrum mundi, chrystianizm jezuicki

ANNA AL-ARAJ, doktorantka na Wydziale Polonistyki Uniwersytetu Jagiellońskiego, absolwentka muzykologii i filologii polskiej, Uniwersytet Jagielloński w Krakowie; e-mail: annaa.alaraj@gmail.com 
Maciej Kazimierz Sarbiewski cieszył się w XVII i XVIII wieku bodaj największą europejską sławą spośród polskich poetów „ery przed-mickiewiczowskiej”. Erudyta, któremu nieobce były tajniki teologii, filozofii i poetyki, autor traktatów teoretycznych, wielu dzieł lirycznych ${ }^{1}$ oraz zachowanego we fragmentach eposu Lechiada ${ }^{2}$. I wreszcie - zaaferowany licznymi obowiązkami dydaktyk i duszpasterz, ubolewający nad niemożnością skoncentrowania się na własnej twórczości: „Próżno bym się wymawiał z mojego milczenia albo chorobą, która nas często nawiedza, albo Lechiadą, do której znowu powracam, albo ustawicznymi kazaniami"s.

Już na podstawie tego krótkiego wprowadzenia nietrudno się zorientować, że mamy do czynienia z poetą intrygującym, który pozostawił potomnym bardzo wartościowe i godne uwagi dzieło. Tym bardziej dziwi zatem fakt wybiórczej znajomości jego dokonań, w praktyce ograniczonej niemal wyłącznie do kręgu filologów. Oczywiście usprawiedliwień może być wiele: bariera językowa, zmiana paradygmatu kultury europejskiej w II połowie XIX wieku i przyjmowanie wzorców przez nią ukształtowanych za punkt odniesienia podczas interpretacji literackiego dorobku ery przed-romantycznej. Trudno jednak z pokorą zgodzić się na te wyjaśnienia, mając świadomość artystycznej rangi liryka z Sarbiewa, uhonorowanego w 1623 roku przez papieża Urbana VIII laurem poetyckim (a także złotym medalionem), a potem - wedle całkiem prawdopodobnych domniemywań - wygnanego przezeń z Rzymu z powodów czysto ambicjonalnych ${ }^{4}$.

\footnotetext{
${ }^{1}$ Zgodnie z wyliczeniami Mirosława Korolki, na trzon dorobku poetyckiego Sarbiewskiego składają się 133 ody i 145 epigramatów. Zob. Maciej Kazimierz Sarbiewski, Liryki oraz Droga rzymska i fragment Lechiady, tłum. Tadeusz Karyłowski, oprac. Mirosław Korolko, Jan Okoń (Warszawa: Instytut Wydawniczy PAX, 1980), 21.

${ }^{2}$ Nie wiadomo, czy dzieło to, stylizowane na Eneidę Wergiliusza, zostało przez poetę ukończone. Korolko snuje przypuszczenia - poparte relacją zawartą w jezuickiej bibliografii z 1676 roku - że Sarbiewski napisał cały utwór, którego 12 ksiąg było „dostępnych” do końca XVII wieku. Zob. tamże.

${ }^{3}$ Sarbiewski, Liryki oraz Droga rzymska i fragment Lechiady, 24.

${ }^{4}$ Papież Urban VIII, parający się także twórczością poetycką, nie potrafił ponoć zaakceptować faktu bycia przewyższanym przez Sarbiewskiego w zakresie sztuki operowania słowem. Gorącą polemikę na ten temat wywołała publikacja Józefa Warszawskiego pt. „Dramat rzymski” Macieja Kazimierza Sarbiewskiego TJ(1622-1625). Studium literacko-biograficzne, Rzym 1984.
} 
Akceptację istniejącego stanu rzeczy uniemożliwiają ponadto świadectwa popularności liryków Sarbiewskiego w Niderlandach Południowych i Północnych ${ }^{5}$, pod którą podwaliny położyły najpierw jezuicki humanizm ${ }^{6}$, a następnie ponad dwuletni pobyt poety w Rzymie (1622-1625). Chrześcijański Horacy przewyższył sławą cenionych wcześniej na tym obszarze Jana Dantyszka i Szymona Szymonowica. Potem było już tylko lepiej - powstawały liczne przekłady i parafrazy utworów Sarbiewskiego na języki wernakularne ${ }^{7}$, samemu zaś zainteresowanemu przypadło stałe miejsce w obrębie kultury literackiej XVIII i I połowy XIX wieku.

„Europejskość” poety nie ograniczała się jednak wyłącznie do zasięgu oddziaływania. Odrębny problem stanowi tzw. europejskość upodmiotowiona Sarbiewskiego, a więc niejako zdeponowana przez niego w tekście, na co zwraca uwagę Andrzej Borowski ${ }^{8}$. Autor wskazuje na podstawowe wyznaczniki omawianego zjawiska, do których należą: chrystianizm (a dokładniej - chrystianizm jezuicki), łacińskość kultury literackiej (przyjmująca formę horacjanizmu'), ścisła więź poety i poezji z instytucją szkoły i z wychowaniem (i wynikający z niej typowy

\footnotetext{
${ }^{5}$ Kwestia ta zostaje szczegółowo omówiona przez Andrzeja Borowskiego w artykule „Obecność Sarbiewskiego w literaturze europejskiej”, w: Nauka z poezji Macieja Kazimierza Sarbiewskiego SJ. Praca zbiorowa, red. Jacek Bolewski, Jakub Zdzisław Lichański, Piotr Urbański (Warszawa: Collegium Bobolanum, 1995), 189-204. Konstatacja autora dotycząca tego problemu brzmi: „Sława Sarbiewskiego w Niderlandach przekraczała granice wyznaniowe i polityczne, zdobył on bowiem uznanie nie tylko katolików, lecz także i protestantów w Niderlandach Północnych" (tamże, 202).

${ }^{6} \mathrm{Na}$ związek szerokiego zasięgu duszpasterskiego oddziaływania Towarzystwa Jezusowego i przenikania jego duchowości do różnych środowisk z europejską sławą poety wskazuje Piotr Urbański w artykule „Poezja Sarbiewskiego wobec duchowości ignacjańskiej”, w: Nauka z poezji Macieja Kazimierza Sarbiewskiego SJ, 112-124.

${ }^{7}$ Ody Sarbiewskiego przekładali na język niemiecki m.in. Johann Gottfried Herder czy Robert Schumann. Warto zwrócić uwagę, że historia zatoczyła w tym miejscu koło - badacze podkreślają bowiem swoisty germanofilizm Sarbiewskiego, sygnowany chociażby przez ody do cesarza Ferdynanda II (II. 1, II. 12) czy odę Do Niemiec (II. 23).

${ }^{8}$ Borowski, „Obecność Sarbiewskiego w literaturze europejskiej”, 189.

${ }^{9}$ Obfite czerpanie przez Sarbiewskiego z Horacjańskich wzorców przyczyniło się do nadania mu zaszczytnego miana „chrześcijańskiego/sarmackiego/polskiego Horacego”. Warto jednak zauważyć, że inspiracja ta nie ma charakteru mechanicznego, gdyż: „[... [ silnie widoczna jest także chęć przeciwstawienia się Horacemu. Dlatego w refleksji metaliterackiej sztafaż klasyczny przenikają treści religijne, zaś w wywodach dotyczących spraw ludzkich na świecie Horacjuszowy epikureizm zastępują chrześcijańskie cnoty, ujęte w perspektywie platonizmu i stoicyzmu”. Zob. Elwira Buszewicz, „Maciej Kazimierz Sarbiewski - ody refleksyjne i religijne”, w: Lektury polonistyczne. Średniowiecze - Renesans - Barok, t. 3, Barok, red. Janusz Stanisław Gruchała (Kraków: Universitas, 1999), 121.
} 
dla kultury europejskiej wzorzec paidei) oraz poczucie „północnej odrębności” (nazywanej przez Borowskiego septentrionalizmem). Do tego zestawu warto dodać obfite czerpanie z - przede wszystkim antycznej, lecz niekoniecznie rzymskiej - tradycji literackiej epok ubiegłych, umiejętnie łączonej przez liryka ze współczesnymi mu wzorcami tematycznymi i poetyckimi, a nawet - z prywatną ideologią ${ }^{10}$.

\section{Poetyka sformułowana Sarbiewskiego ${ }^{11}$}

Maciej Kazimierz Sarbiewski należy do autorów, których dorobek daje się interpretować w odwołaniu do założeń teoretycznych. Myśli zawarte w jego traktatach poetyckich znajdują zazwyczaj bezpośrednie przełożenie w artystycznej spuściźnie, co - w wielu przypadkach - nakierowuje analizę na właściwy trop. Ta wspólnota poglądów Sarbiewskiego-literata i Sarbiewskiego-teoretyka sprawia, że jawi się on jako niezwykle dojrzała, posiadająca ugruntowane przekonania na temat sztuki i możliwości jej urzeczywistniania osobowość twórcza. Powstanie rozpraw poświęconych poetyce autorstwa chrześcijańskiego Horacego datuje się na okres po jego powrocie do kraju, a więc po 1625 roku. W Połocku pisze Sarbiewski cztery traktaty: De acuto et arguto, Characteres lirici, De virtutibus et vitiis carminis elegiaci oraz De perfecta poesi. Po przeniesieniu się jezuity do Wilna powstaje zaś Dii gentium.

Do naczelnych problemów teoretycznych poruszanych przez Sarbiewskiego należy rola poety. Powinien on być także filozofem ${ }^{12}$, wskazywać na istotę dobra i piękna, pobudzać do refleksji za pomocą swoich utworów, poszukiwać głębi czy istoty bytu. Co jednak ważniejsze, ma on w koncepcji jezuity rysy boskie ${ }^{13}$ : „Podobnie jak Bóg, stwarzając jakikolwiek byt, stwarza z nim równocześnie to

${ }^{10}$ Mam tutaj na myśli niezwykle wyraziście zaznaczającą się w lirykach Sarbiewskiego chrześcijańską postawę. Mówiąc o „współczesnych” wzorcach tematycznych, warto zwrócić uwagę na liczne odwołania do tzw. problemu tureckiego oraz na panegiryczną twórczość sarmackiego Horacego.

${ }^{11}$ Posłużenie się anachronicznym w tym przypadku podziałem na poetyką immanentną i sformułowaną podyktowane jest względami retorycznymi.

${ }^{12}$ Oczywiście przy uwzględnieniu zasadniczych różnic w zakresie „materii” poetyckiej i filozoficznej.

${ }^{13}$ Nie oznacza to jednak, że posiada zdolność tworzenia ex nihilo, tak jak Bóg. Kreatorska zdolność poety polega na nadawaniu rzeczom kształtów, których nie miały wcześniej. 
wszystko, co wedle wymagań jego natury jest mu potrzebne do ozdoby, życia i zachowania $\mathrm{w}$ istnieniu, tak również poeta stwarza w swej wyobraźni ową wielką zamkniętą w sobie jedną czynność bohatera w ten sposób, że stwarza również inne rzeczy dla jej jakby całości i pewnego rodzaju życia"14.

Z przekonaniem tym wiąże się ustanowiona przez sarmackiego Horacjusza hierarchia sztuk, w której zaszczytne pierwsze miejsce, jak można się domyślać, przysługuje poezji. Ta bowiem powołuje do życia to, co nie istnieje, zarówno $\mathrm{w}$ treści, jak też w sposobie opracowania ${ }^{15}$. Element kreacjonizmu przypisany osobie działającej w materii słowa stanowi ponadto wyróżnik wobec aktywności historyka czy oratora. Poeta creator nie mówi wyłącznie o tym, co było (tak jak historyk) i przedstawia to, czego w ogóle nie było i być nie mogło (w przeciwieństwie do oratora). Warto zaznaczyć, że w odniesieniu do procesu twórczego sarmacki Horacy proponuje rozwiązanie kompromisowe: nie negując koncepcji furor poeticus, zwraca jednocześnie uwagę na jej racjonalny wymiar (którego pozbawione są innego rodzaju „szały”: miłosny czy mistyczny).

Wiele interesujących spostrzeżeń na temat związku poezji ${ }^{16} \mathrm{z}$ rzeczywistością empiryczną dostarcza exemplum szewca ${ }^{17}$ : „Szewc, mając do czynienia z ułomną, okaleczoną nogą żywą [...], sporządza najpierw nogę drewnianą, jako formę poprawiającą niedostatki wzorca, i dopiero na tej podstawie wykonuje but, który jest jakby »sztuczną nogą" (pes arte factus), zewnętrznym naśladownictwem nogi żywej”18. Podobnie poeta obserwuje historię z jej niedoskonałościami (historia), by potem połączyć ją z wzorcami doskonałymi danymi przez fantazję (argumentum) i wreszcie - oczyścić obrazy i zakomponować przedstawienie ulepszonego świata

${ }^{14}$ Maciej Kazimierz Sarbiewski, O poezji doskonałej, czyli Wergiliusz i Homer, tłum. Marian Plezia, oprac. Stanisław Skimina (Wrocław: Ossolineum, 1954), 153.

${ }^{15}$ „Poezja bowiem tak odtwarza coś czy naśladuje, że zarazem stwarza to, co naśladuje, i jak gdyby na nowo powołuje do życia, nie tak jak inne sztuki, które jedynie naśladują i odtwarzają, ale nie stwarzają, bo zakładają istnienie bądź to materiału, z którego tworzą, bądź to tematu, bądź przynajmniej tego, przy pomocy czego naśladują". Zob. tamże.

${ }^{16}$ Czy w ogóle twórczości literackiej, gdyż za idealną realizację swoich założeń teoretycznych (ars nobilissima) uznaje Sarbiewski w De perfecta poesi epos.

${ }^{17}$ Zob. Andrzej Lam, „Exemplum szewca w poetyce Sarbiewskiego”, w: Maciej Kazimierz Sarbiewski i jego epoka. Próba syntezy, red. Jakub Zdzisław Lichański (Pułtusk: Akademia Humanistyczna im. Aleksandra Gieysztora, 2006), 187-192.

${ }^{18}$ Tamże, 188-189. 
(fabula). Taki przebieg procesu twórczego (jednostkowe - uniwersalne - jednostkowe), polegający na „ponownym stwarzaniu” rzeczywistości, dał Sarbiewskiemu asumpt do porównania artysty-kreatora do Boga ${ }^{19}$.

Niezwykle zajmującym punktem koncepcji poetyckiej chrześcijańskiego Horacego jest łączenie konieczności posługiwania się alegorią ${ }^{20} \mathrm{z}$ możliwościami percepcyjnymi czytelników ${ }^{21}$. Zdaniem Sarbiewskiego, zabieg alegoryzacji stanowi rodzaj „zasłony”, dzięki której tekst zyskuje na przystępności, co ma niebagatelne znaczenie w przypadku „niewtajemniczonych” odbiorców (indoctì). Inną funkcję pełni owo „zaciemnianie przekazu” w odniesieniu do świadomych czytelników (docti ) - pobudza ich do wydobywania sensów ukrytych, niedostępnych podczas literalnej lektury. Rozważania te ściśle wiążą się z koncepcją tzw. fabulosa theologia, będącej - mówiąc wprost - próbą doszukiwania się znamion teologii chrześcijańskiej w dorobku pogańskiego antyku. Oddajmy głos Sarbiewskiemu:

A zaiste sądzę, że te skrupuły u niektórych spowodowane są nie tyle jakąś surowością lub ostrością sądów, lecz winę ponosi tu niewiedza i jakieś przestarzałe przekonanie, że starożytni wymyślili tylko przypadkowe bajki i że nic pod nimi, jak pod zasłoną, nie kryje się, czy to filozoficznego, czy teologicznego. A przecież ślepe pogaństwo śniło pod obrazem mitu o wiecznym pochodzeniu Słowa (czyli prawdy wcielonej $)^{22}$.

Poeta z Sarbiewa w swoim rozumowaniu posuwa się jeszcze dalej - przypisując działaniom twórców antycznych intencjonalność:

bynajmniej nie zmyślali oni lekkomyślnie mitów (fabulas), nawet tych, które na pierwszy rzut oka wydają się najbardziej nieprzyzwoite, lecz że ukryli oni w nich

\footnotetext{
${ }^{19}$ Podobny trzyfazowy model pracy twórczej zaproponował Juliusz Caesar Scaliger: imitare - kopiowanie rzeczywistości, certare - połączenie realności z idealnymi formami, superare - udoskonalenie realności w jej przedstawieniu.

${ }^{20} \mathrm{Za}$ istotę poezji uznaje Sarbiewski pośrednio udzielaną naukę, a więc docere oblique. Znamienne, że w lirykach jezuity - apologety alegoryzacji, najczęściej przywoływanym kontekstem biblijnym jest Pieśń nad Pieśniami, jedna z najbardziej obrazowych ksiąg Pisma Świętego. Wszystkie wyróżnienia, jeżeli nie zaznaczono inaczej, pochodzą od autorki artykułu.

${ }^{21}$ A mówiąc prościej - z ich wiedzą i z oczytaniem w tekstach kultury.

${ }^{22}$ Zbigniew Grochal, „Posłannictwo poety-filozofa w ujęciu Macieja Kazimierza Sarbiewskiego”, w: Nauka z poezji Macieja Kazimierza Sarbiewskiego SJ, 129. Na marginesie warto zwrócić uwagę na tytuł rozprawy, z której pochodzą przywoływane słowa (Dii gentium), w języku polskim oddawany jako Bogowie pogan, bezpośrednio odsyłający do problematyki związanej z „bajeczną/fabularną teologią”.
} 
wiele rzeczy odnoszących się do obu filozofii, tj. naturalnej i moralnej, co więcej nawet do teologii, a cenną prawdę, jak niezwykłej wartości obraz, osłonili jakby zasłoną mitów dla zapewnienia jej większej dostojności²3.

Taką, wydaje się, że dość kontrowersyjną, postawę chrześcijańskiego Horacego w niezwykle interesujący sposób komentuje Jacek Bolewski. Badacz dostrzega w koncepcji fabulosa theologia wpływ formuły jezuickiej, głoszącej, aby znajdować Boga we wszystkim ${ }^{24}$. Uwzględnienie tego rodzaju perspektywy pozwala zmodyfikować ocenę dywagacji Sarbiewskiego. Jawi się on wówczas jako jednostka otwarta na przyjęcie tego, co odmienne, niezgodne $\mathrm{z}$ jego przekonaniami, jako poeta daleki od potępiania i skory do zrozumienia (bądź co bądź - na swój własny sposób) kulturowego dorobku minionych epok ${ }^{25}$.

\section{Poetyka immanentna Sarbiewskiego (na przykładzie OdyIV. 12)}

Inspiracje horacjańskie dostrzegalne są w dziele Sarbiewskiego w obrębie różnych płaszczyzn. Do jednej z ważniejszych zalicza się układ formalny Lyricorum, zarówno u Flakka, jak i u barokowego autora znamionowany przez swoistego rodzaju „rozłam stylistyczny” następujący po domknięciu księgi III ${ }^{26}$. Pieśni z kolejnego tomu poezji Horacego - jak twierdzą badacze - charakteryzuje sceptycyzm i odwrót od proklamowanego wcześniej hasła carpe diem, co wiązać się może z rozczarowaniem głoszonymi przez Rzymianina w utworach z ksiąg I, II

${ }^{23}$ Jacek Bolewski, „Nascitur una... discors concordia. Aspekty teologiczne twórczości Sarbiewskiego", w: Nauka z poezji Macieja Kazimierza Sarbiewskiego SJ, 97.

${ }^{24}$ Tamże, 87-111.

${ }^{25}$ Pozwolono sobie na omówienie wyłącznie kilku problemów dotyczących „poetyki sformułowanej” Sarbiewskiego, zdaniem autorki najistotniejszych dla dalszych rozważań. Pominięto chociażby zagadnienie pointy i dowcipu czy - związanej z nimi - discors concordia. Na Horacjańską genezę tego doskonale wpisującego się przecież w barokową estetykę - chwytu poetyckiego wskazuje Lech Bobiatyński w artykule „Horacjańskie źródła motywów stoickich w poezji Macieja Kazimierza Sarbiewskiego”, w: Wątki neostoickie w literaturze polskiego renesansu i baroku, red. Piotr Urbański (Szczecin: Wydawnictwo Naukowe Uniwersytetu Szczecińskiego, 1999), 201.

${ }^{26}$ Co ciekawe, między powstaniem pierwszego i drugiego zbioru liryków zarówno Horacy, jak i Sarbiewski działali głównie na polu filozofii. 
i III ideami (także politycznymi). Podobna sytuacja ma miejsce w przypadku jezuity - niewątpliwym przełomem było dla niego opuszczenie Rzymu w 1625 roku, które w znaczący sposób zaważyło na jego stanie psychicznym ${ }^{27}$. Jak konstatuje Piotr Urbański, zasadnicza różnica zachodząca między lirykami powstałymi przed i po pobycie sarmackiego Horacjusza w Wiecznym Mieście polega na obecności w utworach późniejszych (także tych wtórnie dołączonych do ksiąg I-III) motywów ignacjańskich ${ }^{28}$.

Do dzieł literackich Sarbiewskiego zaczynają zatem przenikać po 1625 roku elementy i pojęcia kojarzone z doktryną zakonu św. Ignacego Loyoli: agere contra (aktywne przeciwstawianie się pokusom i złu), święta obojętność, zwyciężanie samego siebie, nieufność wobec subiektywizmu przeżyć wewnętrznych, problematyka związana $\mathrm{z}$ dobrym wyborem, z poszukiwaniem własnej wolności w procesie samokontroli czy ze specyficzną wartością samotności. Wszystkie wymienione postulaty, wraz z koniecznością uporządkowania życia i własnych wypowiedzi ${ }^{29}$ zalecaną przez założyciela zakonu jezuitów („Nie mówić słów próżnych. [...] we wszystkim [...] jest rzeczą zasługującą mówić w sposób dobrze uporządkowany, a znów grzechem jest mowa nieuporządkowana i bezużyteczna"30), znalazły odzwierciedlenie nie tylko w twórczości poetyckiej chrześcijańskiego Horacego, ale także w jego stosunku do rzeczywistości. Wspomina on: „Zresztą tak bardzo pogrążyłem się w samotności, tak bardzo zatopiłem się w mych księgach i w [najsłodszym] odpoczynku, że nie tylko pióro moje, ale nawet oczy i usta nie wychylają się poza moją katedrę. Codziennie lepiej poznaję, że nie ma nic bezpieczniejszego i nic słodszego nad milczenie" 31 .

Silne utożsamienie się Sarbiewskiego z tradycją ignacjańską mogło również wpłynąć na sposób rozumienia przez niego posłannictwa poezji. Zgodnie z tym, co głosili mistycy, piękno i sztuka chronią przed rozpaczą i posiadają moc integrowania rozbitej osobowości. A taka, jak przekonują świadectwa, była osobowość

${ }^{27}$ Wiemy o nim z notatki pozostawionej przez instruktora trzeciej probacji Sarbiewskiego, o. Wawrzyńca Bartiliego SJ, który przybliża zachowanie poety podczas wielkich rekolekcji odbytych w Nieświeżu na przełomie 1625 i 1626 roku.

${ }^{28}$ Piotr Urbański, „Poezja Sarbiewskiego wobec duchowości ignacjańskiej”, w: Nauka z poezji Macieja Kazimierza Sarbiewskiego SJ, 113.

${ }^{29}$ Można przypuszczać, że zalecenie to odnosiło się także do twórczości literackiej.

${ }^{30}$ Urbański, „Poezja Sarbiewskiego wobec duchowości ignacjańskiej”, 116.

${ }^{31}$ Bobiatyński, „Horacjańskie źródła motywów stoickich w poezji Macieja Kazimierza Sarbiewskiego", 209. 
twórcy, w momencie gdy utracił on wiarę w możliwość artystycznego spełnienia w stolicy chrześcijaństwa.

Za realizację motywu nieufności wobec subiektywizmu uczuć wewnętrznych należy uznać manierę adresowania liryków z okresu po-romańskiego do postaci fikcyjnych ${ }^{32}$. Zdaniem Urbańskiego, chwyt ten pełni funkcję maski, umożliwiającej twórcy swobodne zwerbalizowanie - i jednocześnie uogólnienie - swoich doświadczeń i refleksji. Wprowadzenie takiego zabiegu daje ponadto szansę na przezwyciężenie przyrodzonej człowiekowi skłonności do oceniania świata wyłącznie $\mathrm{z}$ własnej perspektywy ${ }^{33}$.

Inną cechą charakterystyczną ód z drugiego zbioru, również wywodzącą się z założeń ignacjańskich, jest zestawianie na zasadzie opozycji wartości pozornych bądź kwestionowanych przez autora (doczesność, świeckość, pogaństwo) i wartości prawdziwych (religia, chrześcijaństwo), czasem dookreślanych przez epitety o pozytywnych konotacjach: wieczny, niebiański ${ }^{34}$. Najczęściej spotykane konstrukcje dychotomiczne to: sława i prawdziwa sława, zwodnicza chwała i mądrość Boża, „rozgłośna” sława i rzeczywista, do końca niepoznawalna wartość człowieka, sława pierzchliwa i prawdziwa chwała, pozór cnoty i cnota prawdziwa, zasługa i prawdziwa zasługa.

Większość utworów powstałych po 1625 roku unifikuje także refleksyjny, osobisty, czasem konfesyjny ton. Zgodnie z zaleceniami teoretycznymi poety, ich przedmiotem są zazwyczaj „krótkie sceny i omawianie prawd ogólnych””35. Podmiot tekstowy ód robi „na oczach czytelnika” szeroko pojęty rachunek sumienia ${ }^{36}$, umożliwiający dotarcie do prawdziwego „ja”, poznanie, a tym samym - „wzięcie w posiadanie” samego siebie, zapewniające upragnioną niezależność:

\footnotetext{
${ }^{32} \mathrm{Na}$ konieczność poszukiwania powiązań między treścią utworu a imionami adresatów, również w zakresie ich etymologii, wskazuje Bobiatyński. Zob. tamże, 192.

${ }^{33}$ Elwira Buszewicz mówi o konwencji soliloquium - dialogu wewnętrznego, zgodnego z dyrektywami etycznymi zakonu jezuitów. Zob. Buszewicz, „Maciej Kazimierz Sarbiewski - ody refleksyjne i religijne", 125.

${ }^{34}$ Dla oddania sprawiedliwości, należy dopowiedzieć, że poczucie pozornej wartości wielu zjawisk znamionuje już pierwszy zbiór ód Sarbiewskiego. Konstatacja ta skłania do rozpatrywania drogi twórczej chrześcijańskiego Horacego raczej w perspektywie ewolucji niż wyraźnej przełomowości (co sugerowałoby, być może zbyt ostre, sformułowanie „rozłam stylistyczny”).

${ }^{35}$ Buszewicz, „Maciej Kazimierz Sarbiewski - ody refleksyjne i religijne”, 117.

${ }^{36}$ To jedna z najważniejszych form aktywności duchowej według św. Ignacego Loyoli.
} 
Qui refugit sui

Rex esse, regni nesciet exteri;

Quicumque dat sibi, regendo

Ille potest dare iura mundo.

[Kto samemu sobie

Nie władnie, próżno o posłuch nastawa,

Kto sobie władnie, może w każdej dobie

Całemu wokół światu pisać prawa.] $]^{37}$ (IV. 31, 25-28)

Pomyślną realizację postulatów dotyczących konieczności władania samym sobą, oceny indywidualnych poruszeń duchowych i dotarcia do istoty rzeczy zapewniają odosobnienie, zacisze oraz milczenie.

Powyższe refleksje na temat miejsca i zasięgu topiki ignacjańskiej w dziele sarmackiego Horacego w znacznym stopniu przybliżają krąg idei, do którego odsyła Oda IV. 12 Do Jana Libiniusza. Usprawiedliwienie swej samotności ${ }^{38}$. Bezpośredni zwrot do adresata, zaznaczony zarówno w tytule utworu, jak i w jego exordium, nawiązuje do jednego z zalecanych przez Sarbiewskiego modeli charakterów lirycznej dyspozycji, cechującego się przyjacielskim (czyli wytwornym) rozpoczęciem, niezawierającym niczego zdumiewającego ani rzadkiego:

Quid me latentem sub tenui lare

Dudum moretur, cum mihi civium

Amica certatim patescant

Atria, saepe rogas, Libini. ${ }^{39}$

[Dlaczego $[\ldots]$

Pytasz mnie często, mój Libiniuszu... $]^{40}$

[Pytasz, Libiński...] ${ }^{41}$

\footnotetext{
${ }^{37}$ Sarbiewski, Liryki oraz Droga rzymska i fragment Lechiady, 347.

${ }^{38}$ Alternatywna wersja tytułu - w tłumaczeniu Tadeusza Karyłowskiego - brzmi: Do Janusza Libińskiego. Usprawiedliwia swe odosobnienie. Interpretacja przeprowadzona jest w zasadniczej swej części w oparciu o przekład Elwiry Buszewicz. Wydaje mi się, że skrajna regularność rytmiczna wsparta stałym schematem rymów, znamionująca wersję Karyłowskiego, w mniejszym stopniu oddaje mnogość pokładów znaczeniowych tekstu.

${ }^{39}$ Maciej Kazimierz Sarbiewski, Ziemskie pielgrzymowanie. Wiersze wybrane, tłum. Elwira Buszewicz (Kraków: Universitas, 2003), 118.

${ }^{40}$ Tamże, 119.

${ }^{41}$ Sarbiewski, Liryki oraz Droga rzymska i fragment Lechiady, 347.
} 
Tego rodzaju formuły inicjalne - niepozbawione zdaniem poety z Sarbiewa rysów powabu, powagi i dostojności - mają swoje źródło w twórczości Horacego. $\mathrm{O}$ ile nie dziwi poufałość tonu, z jaką podmiot tekstowy zwraca się do wyimaginowanego odbiorcy, o tyle pytanie retoryczne, które do niego kieruje, może przyprawiać o dezorientację. Przy jego pomocy bowiem w sposób stanowczy wtajemnicza się czytelnika w bardzo intymną sferę przekonań i wartości rządzących życiem człowieka. W jej obręb wpisuje się przywołana przez „ja” kategoria samotności. Przełamanie tabu, do jakiego dochodzi już w formule inicjalnej, niejako automatycznie uruchamia konfesyjny ton, typowy dla liryków przyjmujących formę „rachunku sumienia”.

Dalsze partie tekstu, jak można się domyślać, stanowią realizację schematu argumentacji - tytułowego usprawiedliwienia, przeprowadzanego jednak w charakterystyczny dla Sarbiewskiego sposób. Naczelną zasadą organizującą „odpowiedź" jest dychotomia. W tym utworze, podobnie jak w innych dziełach z okresu po-romańskiego, świat pozoru, ułudy, snu, reprezentowany przez motyw theatrum mundi, zostaje przeciwstawiony temu „prawdziwemu”, o niepodważalnej wartości. Wydaje się, że to zestawienie stanowi rzadziej spotykany - „horyzontalny” wariant sytuacji lirycznych rozgrywających się wokół osi wertykalnej ${ }^{42}$. Opozycyjne pary tworzy zatem już nie „góra” i „dół”, lecz to, co wewnątrz i na zewnątrz. Wszystko to, co przynależy do sfery intra („,scena ducha”, metafora domu z zamkniętymi drzwiami, „prywatna cnota”), jest oceniane pozytywnie, zaś wyróżniki płaszczyzny extra („wyścigi”, „świadectwo ludu”, „krzykliwa chwała”, „usta gminu”) mają zdecydowanie pejoratywny wydźwięk. Odwołanie do toposu życia-teatru (vitae theatrum), pojawiające się w dalszej części utworu, determinuje zmianę optyki - podmiot tekstowy dystansuje się bowiem wobec roli przez niego odgrywanej, stara się zracjonalizować proces „wchodzenia w partię”, aby mieć realny wpływ na jej kształt i - w efekcie - spodobać się Bogu-dramaturgowi ${ }^{43}$ :

${ }^{42} \mathrm{U}$ Sarbiewskiego $\mathrm{z}$ wymiarem sakralnym nieba związana jest pionowa hierarchia wartości, oparta na dualizmie tego, co „w górze” (doskonałość), i tego, co „w dole” (marność). Zob. Maria Łukaszewicz-Chantry, Trzy nieba. Przestrzeń sakralna w liryce Macieja Kazimierza Sarbiewskiego (Wrocław: Wydawnictwo Naukowe Uniwersytetu Wrocławskiego, 2002).

${ }^{43} \mathrm{Na}$ uwagę zasługuje związek między realizacjami toposu theatrum mundiw twórczości Sarbiewskiego i Calderona de la Barca, którego najbardziej znane dzieła (El gran teatro del mundo, La vida es sueño) powstały w podobnym czasie, co „późne” liryki Sarbiewskiego. Ciekawym wątkiem jest też zbieżność między motywem teatru świata a poglądem stoickim. W dorobku sarmackiego Horacego zaznacza 
In se recedentis Treviso

Scaenam animi, vucuumque lustro

Vitae theatrum; sollicitus mei

Spectator, an, quae fabula prodii,

Matura procedam, et supremo

Numinis excipienda plausu. ${ }^{44}$

[A gdy oglądam ten próżny teatr

Mojego życia, troszczę się jako widz

Samego siebie, aby ta moja gra

Wypadła dobrze, Najwyższego

Boga zyskując upodobanie.] ${ }^{45}$

Obserwator - a jednocześnie uczestnik - kukiełkowej maskarady za godny uwagi uznaje wyłącznie werdykt inicjatora przedstawienia. Kruchość, marność i niestałość ludzkich osądów czy decyzji wywołuje w nim gorycz, odrazę. Tego rodzaju postawa „ja” mówiącego odsłania kolejny istotny kontekst - dystansu między poetą-wieszczem a tłumem, ukazujący, że odwrót od życia (czy raczej jego pozorów) nie musi wiązać się z obniżeniem poczucia własnej wartości, wręcz przeciwnie. Świadomość efemeryczności sławy panującej w świecie iluzji (Fama) i jej zależności od ludzkich słabości (zazdrości, zawiści) przysparza podmiotowi tekstowemu powodów do chluby. Nie jest on narażony na nierzadko bardzo bolesne upadki. Sugestywność tego obrazu multiplikuje figura kathabasis, eksponująca ruch w dół:

Illa nudam

Plangit humum, lacerosque saris

Affligit artus. ${ }^{46}$

[Potem w nagą

Ziemię uderza i rani ciało

O skały ostre. $]^{47}$

się zwłaszcza inspiracja filozofią Seneki, wykazującej powinowactwo z ideami chrześcijańskimi. W De acuto et arguto znajduje się ponadto pełna uznania wzmianka na temat stylu pisarskiego tego myśliciela.

${ }^{44}$ Sarbiewski, Ziemskie pielgrzymowanie, 118.

${ }^{45}$ Tamże, 119.

${ }^{46}$ Tamże, 118.

${ }^{47}$ Tamże, 119. 
Wspomniany motyw dystansu między twórcą a „resztą” można także analizować w odniesieniu do dialogu poety z Horacym. Wydaje się bowiem, że to topika odi profanum vulgus et arceo (Hor. Carm. III. 1) stanowiła dla Sarbiewskiego bezpośredni impuls do rozważań na temat istoty samotności. Odę Flakka otwiera sugestywna eksklamacja: „Precz, motłoch ciemny! Cóż mię on obchodzi?”48, wiążąca twórczość poetycką z pewnego rodzaju „wiedzą tajemną”, dostępną nielicznym. Zlokalizowanie aktywności artystycznej w sferze szeroko pojętego elitaryzmu samo przez się odsyła do kategorii milczenia, a ta z kolei - do odosobnienia. Ten sposób rozumowania ściśle koresponduje $\mathrm{z}$ właściwą podmiotowi tekstowemu $O d y$ IV. 12 niechęcią do wrzaskliwego tłumu:

Odi loquacis compita gloriae

Plaebeia.

[Krzykliwą chwałą, którą na drogach tłum

Roznosi, gardzę. $]^{49}$

W Carmen Horacego w równie silnym co u Sarbiewskiego stopniu zostają wyeksponowane elementy wanitatywne:

Konieczność z urny wspólnej bierze,

Małych z wielkimi gdy razem zmięsza. ${ }^{50}$

Uwagę zwraca także podobne ustosunkowanie się twórców do kwestii „stałości charakteru":

Kto rad swej doli, tego nie dotyka

Gwałt mórz burzliwych, ni się on obawia

W Arkturze zgasłych gwiazd bezprawia,

Ni świtających też klęsk Woźnika [...]. ${ }^{51}$

${ }^{48}$ Horacy, Wybór poezji, tłum. i oprac. Jerzy Krókowski (Wrocław: Ossolineum, 2007), 74. Tekst przytaczam w tłumaczeniu Felicjana Faleńskiego.

${ }^{49}$ Sarbiewski, Ziemskie pielgrzymowanie, 118-119.

${ }^{50}$ Horacy, Wybór poezji, 75.

${ }^{51}$ Tamże, 76. 
I wreszcie bodaj najważniejsza analogia - finalne zestawienie ziemskiej Famy i zazdrości (Livor), nieodłącznych towarzyszek ludzkiego życia:

To czemuż miałbym, budząc zazdrość czyją,

Wspaniałych komnat wznosić gdzieś przepychy,

Mieniając za mój domek cichy

Byt, w którym ludzie mozolnie żyją? ${ }^{52}$

Komunikat nadawany przez ,ja” w Odzie IV. 12 brzmi zatem jednoznacznie: godna zaufania jest tylko sława wieczna, wyłącznie ona zapewnia nieśmiertelność. Jej „ziemskie” namiastki, jak mówi Sarbiewski w innym utworze, przyprawiają o ciągły niepokój, wynikający z konieczności „gonienia” za tym, co bezustannie nam umyka:

Laete, quid cassis sequimur fugacem

Gloriam telis? Fugit illa Mauri

More, vel Parthi, regeritque ab ipso

Vulnera tergo.

[Po co, Letusie, za sławą pierzchliwą

Namiętnie gonić? Wciąż ona ucieka

Jak Maur lub Party i zdradną cięciwą

Razi z daleka.] ${ }^{53}$ (IV. 11, 1-4)

Tymczasem:

Vera laus sciri fugit. Ipse pulcher

Se sua Titan prohibet videri

Luce: qui totus potuit latere,

Maior habetur.

[Prawdziwa chwała lubi ustroń. Zorze

Słoneczne kryje ich światłość jaskrawa;

Kto się zupełnie przed okiem skryć może,

Większym się stawa.] ${ }^{54}$ (IV. 11, 13-16)

${ }^{52}$ Tamże, 76.

${ }^{53}$ Łukaszewicz-Chantry, Trzy nieba. Przestrzeń sakralna w liryce Macieja Kazimierza Sarbiewskiego, 61 .

${ }^{54}$ Tamże, 61. 
Trwałe poczucie bezpieczeństwa zapewnia podmiotowi tekstowemu OdyIV. 12 prywatna cnota (privata virtus) $)^{55}$. Ona to niczym tarcza uodparnia go na ciosy z zewnątrz i zmienność Fortuny:

\author{
Me melius tegat \\ Privata virtus, et popularia \\ Numquam volaturum per ora \\ Celet iners sine laude tectum. ${ }^{56}$ \\ [lepiej niech chroni mnie \\ Prywatna cnota; kiedy mój lichy dach, \\ Niegodny chwały, mnie osłoni, \\ Nigdy nie będę na ustach gminu. $]^{57}$
}

Zdobycie virtus - pozwalającej przyjąć postawę dystansu wobec otaczającej rzeczywistości - to niebagatelne osiągnięcie. Przebywa ona bowiem pomiędzy ziemią a niebem, na szczytach stromych gór:

Delli, si populo duce

Vitae degenerem carpimus orbitam,

Erramus; procul arduis

Virtus se nimium seposuit iugis.

[Deliuszu, jeśli obieramy życie,

Jakie prowadzi pospólstwa gmin szary,

Błądzimy: cnota na odludnym szczycie

Mieszka, stromymi otoczonym jary. $]^{58}$ (IV. 10, 1-4)

Można jednak przypuszczać, że podmiotowi tekstowemu Ody IV. 12 udało się posiąść to, co - zgodnie z jego hierarchią wartości - najcenniejsze.

${ }^{55}$ Posługując się personifikacją cnoty, Sarbiewski nawiązuje do antycznych koncepcji, zwłaszcza stoickich, w których Virtus była jedną z najwyższych wartości.

${ }^{56}$ Sarbiewski, Ziemskie pielgrzymowanie, 118.

${ }^{57}$ Tamże, 119.

${ }^{58}$ Łukaszewicz-Chantry, Trzy nieba. Przestrzeń sakralna w liryce Macieja Kazimierza Sarbiewskiego, 63. 
$\mathrm{Na}$ koniec warto zwrócić uwagę na częste występowanie w utworze motywu vanitas. $\mathrm{Na}$ jego obecność wskazują przede wszystkim fragmenty postulujące nieufność wobec pozornych światowych dóbr, ale także - wobec śmiertelnego i ulegającego słabościom człowieka. Taki stosunek do rzeczywistości przywołuje rozmaite konteksty kultury, chociażby biblijne. Nie trzeba sięgać do Księgi Koheleta, aby znaleźć wanitatywne opisy, w które obfitują też np. teksty psalmów. Przytoczmy parafrazę Jana Kochanowskiego ${ }^{59}$ :

\author{
Na króle się nie spuszczajcie, \\ Śmiertelnemu nie ufajcie, \\ Bo ten nie pomoże sobie \\ Pogotowiu ani tobie. \\ Skoro duch wynidzie z ciała, \\ Ziemia ziemię będzie brała, \\ A nasze płonne nadzieje \\ Po powietrzu dma rozwieje. \\ Tu człowiek prawie szczęśliwy, \\ Komu sam Pan jest chętliwy, \\ A on też tylko jednemu \\ Ufa Panu Bogu swemu. ${ }^{60}$ \\ (Psalm 146, Lauda, anima mea, Dominum)
}

\title{
Zakończenie
}

Zawarte w niniejszym artykule refleksje stanowią potwierdzenie tezy o spójności i koherencji dorobku twórczego Macieja Kazimierza Sarbiewskiego. Porównanie postawy życiowej jezuity (o której możemy wnioskować tylko na podstawie

\footnotetext{
${ }^{59}$ Sarbiewski bardzo cenił twórczość Kochanowskiego i stawiał go ponad wszystkich innych znanych mu poetów włoskich, francuskich czy hiszpańskich, gdyż „przewyższa ich wytwornością mowy polskiej, powagą myśli, doborem inwencji, zwłaszcza obrazowej, wreszcie pewną tężyzną (nervo)". Zob. Maciej Kazimierz Sarbiewski, Wykłady poetyki (Praecepta poetica), tłum. i oprac. Stanisław Skimina (Wrocław-Kraków: Ossolineum, 1958), 38. Warto dodać, że Sarbiewski nawiązuje nie tylko do polskich, lecz również do łacińskich utworów Kochanowskiego, na których wzoruje niekiedy kompozycję swoich liryków.

${ }^{60}$ Jan Kochanowski, Dzieła polskie, oprac. Julian Krzyżanowski (Warszawa: Państwowy Instytut Wydawniczy, 1972), 534.
} 
fragmentarycznych relacji, coś jednak komunikujących), jego osiągnięć na polu poetyki, filozofii, teologii czy wreszcie sztuki operowania słowem pozwala skonstatować, że mamy do czynienia z osobowością o bardzo wyrazistych i ustabilizowanych poglądach, projektowanych na różne płaszczyzny artystycznej działalności. Nie oznacza to bynajmniej, że jedyną drogą do odkrycia fenomenu sarmackiego Horacego jest przesadny biografizm. To dzięki wnikliwej analizie pojawiającej się w lirykach metaforyki, celów stawianych poezji czy stosunku autora Dii gentium do tradycji wieków ubiegłych można zauważyć, że jezuita niejako zdeponował się mentalnie w dziele.

Dzieje zarówno życia, jak i twórczości Sarbiewskiego obnażają smutny paradoks - są spełnieniem najczarniejszych wizji z OdyIV. 12. Wygnanie z Rzymu, na wieść - „powodowaną zawiści strzałą” - o nieprzeciętnym talencie sarmackiego Horacego, a potem stopniowe wypieranie ze zbiorowej świadomości dokonań poety zdają się potwierdzać uniwersalność tez o zawodności Sławy uzależnionej od opinii śmiertelników.

Podejmowane przez Sarbiewskiego próby nadania własnej twórczości lirycznej wymiaru ogólnoludzkiego, czego świadectwem są: charakter poruszanych tematów, zwrot ku chrystianizmowi oraz liczne odwołania do zdobyczy przeszłości, powinny stanowić zachętę do praktykowania nowych sposobów odczytań, interpretacji jego dzieł. Szczególnie wartościowe może się w tym przypadku okazać dążenie nie do „uwspółcześniania”, lecz do odnajdywania w tekstach trwałych i niezmiennych sensów, nieuwarunkowanych przez atmosferę epoki, kontekst historyczny czy poziom świadomości społecznej.

\section{Bibliografia}

Literatura podmiotu:

Horacy. Wybór poezji. Tłum. i oprac. Jerzy Krókowski. Wrocław: Ossolineum, 2007.

Kochanowski, Jan. Dzieła polskie. Oprac. Julian Krzyżanowski. Warszawa: Państwowy Instytut Wydawniczy, 1972.

Sarbiewski, Maciej Kazimierz. „Do Jana Libiniusza. Usprawiedliwienie swej samotności” ( Oda IV. 12). W: Maciej Kazimierz Sarbiewski, Peregrinatio terrestris. Carmina selecta / Ziemskie pielgrzymowanie. Wiersze wybrane. Tłum. Elwira Buszewicz, 118-119. Kraków: Universitas, 2003. 
Sarbiewski, Maciej Kazimierz. „Do Janusza Libińskiego. Usprawiedliwia swe odosobnienie” (Oda IV. 12). W: Maciej Kazimierz Sarbiewski, Lyrica quibus accesserunt iter Romanum et Lechiados fragmentum / Liryki oraz Droga rzymska i fragment Lechiady. Tłum. Tadeusz Karyłowski. Oprac. Mirosław Korolko przy współudziale Jana Okonia, 347. Warszawa: Instytut Wydawniczy PAX, 1980.

Sarbiewski, Maciej Kazimierz. De perfecta poesi, sive Vergilius et Homerus / O poezji doskonałej, czyli Wergiliusz i Homer. Tłum. Marian Plezia. Oprac. Stanisław Skimina. Wrocław: Ossolineum, 1954.

Sarbiewski, Maciej Kazimierz. Wykłady poetyki (Praecepta poetica). Tłum. i oprac. Stanisław Skimina. Wrocław-Kraków: Ossolineum, 1958.

Literatura przedmiotu:

Bobiatyński, Lech. „Horacjańskie źródła motywów stoickich w poezji Macieja Kazimierza Sarbiewskiego". W: Wątki neostoickie w literaturze polskiego renesansu i baroku. Red. Piotr Urbański, 191-210. Szczecin: Wydawnictwo Naukowe Uniwersytetu Szczecińskiego, 1999.

Bolewski, Jacek. „Nascitur una... discors concordia. Aspekty teologiczne twórczości Sarbiewskiego". W: Nauka z poezji Macieja Kazimierza Sarbiewskiego. Praca zbiorowa. Red. Jacek Bolewski, Jakub Zdzisław Lichański, Piotr Urbański, 87-111. Warszawa: Collegium Bobolanum, 1995.

Borowski, Andrzej. „Obecność Sarbiewskiego w literaturze europejskiej”. W: Nauka z poezji Macieja Kazimierza Sarbiewskiego. Praca zbiorowa. Red. Jacek Bolewski, Jakub Zdzisław Lichański, Piotr Urbański, 189-204. Warszawa: Collegium Bobolanum, 1995.

Buszewicz, Elwira. „Maciej Kazimierz Sarbiewski - ody refleksyjne i religijne”. W: Lektury polonistyczne. Średniowiecze - Renesans - Barok. T. 3: Barok. Red. Janusz Stanisław Gruchała, 112-137. Kraków: Universitas, 1999.

Grochal, Zbigniew. „Posłannictwo poety-filozofa w ujęciu Macieja Kazimierza Sarbiewskiego”. W: Nauka z poezji Macieja Kazimierza Sarbiewskiego. Praca zbiorowa. Red. Jacek Bolewski, Jakub Zdzisław Lichański, Piotr Urbański, 125-133. Warszawa: Collegium Bobolanum, 1995.

Lam, Andrzej. „Exemplum szewca w poetyce Sarbiewskiego”. W: Maciej Kazimierz Sarbiewski i jego epoka. Próba syntezy. Red. Jakub Zdzisław Lichański, 187-192. Pułtusk: Akademia Humanistyczna im. Aleksandra Gieysztora, 2006.

Łukaszewicz-Chantry, Maria. Trzy nieba. Przestrzeń sakralna w liryce Macieja Kazimierza Sarbiewskiego. Wrocław: Wydawnictwo Naukowe Uniwersytetu Wrocławskiego, 2002.

Urbański, Piotr. „Poezja Sarbiewskiego wobec duchowości ignacjańskiej”. W: Nauka z poezji Macieja Kazimierza Sarbiewskiego. Praca zbiorowa. Red. Jacek Bolewski, Jakub Zdzisław Lichański, Piotr Urbański, 112-124. Warszawa: Collegium Bobolanum, 1995. 
Urbański, Piotr. „Ut pictura poesis w teorii i praktyce poetyckiej Sarbiewskiego”. W: Maciej Kazimierz Sarbiewski i jego epoka. Próba syntezy. Red. Jakub Zdzisław Lichański, 139- 52. Pułtusk: Akademia Humanistyczna im. Aleksandra Gieysztora, 2006.

\section{Summary}

\section{„The vain theatre of life”. To Jan Libiniusz. An excuse for my own solitude (Ode IV. 12) by Maciej Kazimierz Sarbiewski}

The author elaborates on Maciej Kazimierz Sarbiewski's views on poetics and interprets his Ode $I V .12$ (The vain theatre of life. To Jan Libiniusz. An excuse for my solitude) with references to works by Horace and Jan Kochanowski. Quoted are Jesuit Sarbiewski's lyrical works and theoretical treaties as well as essays written about this 'Polish Horace' by Polish literary critics. The first part of the article deals with poetics as interpreted by Sarbiewski, highlighting the role of a poet and the hierarchy of arts as well as the function of allegorization and its relation to the idea of fabulosa theologia. The second part takes up Ignatian themes in his lyrical works written after 1625. References to the doctrine of the Society of Jesus are strongly evident in Ode IV.12 and so are those to the concept of "theatrum mundi" and in particular to Horace's literary works (especially Carmina III.1). The author concludes that the ideas outlined in Sarbiewski's theoretical treatises are consistent with his works in later years.

Keywords: Maciej Kazimierz Sarbiewski, ode, the theatrum mundi concept, Jesuit Christianity

\section{Zusammenfassung}

\section{"Das eitle Theater des Lebens". An Johann Libinius. Die Entschuldigung der eigenen Einsamkeit (Ode IV. 12) von Matthias Kasimir Sarbiewski}

Der Artikel verfolgt das Ziel, die Anschauungen von Matthias Kasimir Sarbiewski über gewählte Fragen der Poetik darzustellen sowie seine Ode IV. 12 An Johann Libinius. Die Entschuldigung der eigenen Einsamkeit in einem vertieften Kontext (Horaz, Jan Kochanowski) zu interpretieren. Die Überlegungen wurden durch Bezüge auf lyrische Dichtung und theoretische Traktate des Jesuiten unterstützt. Eine wertvolle Untermauerung bilden darüber hinaus die Abhandlungen u. a. von Andrzej Borowski, Piotr Urbański oder Elwira Buszewicz über das Schaffen des sarmatischen Horaz. Der Artikel setzt sich aus zwei grundlegenden Teilen, von denen der erste der von Sarbiewski formulierten Poetik gewidmet ist. Die Verfasserin stellt darin die 
Ideen des Denkers über die Rolle des Dichters, die Hierarchie der Künste, die Funktion des Allegorisierungsverfahrens und seine Beziehung zum Konzept von Theologia fabulosa vor. Im nächsten Teil wird auf die Anwesenheit der ignatianischen Motive in der Dichtung des Jesuiten nach 1625 fokussiert. Verweise auf die Doktrin des Ordens des Heiligen Ignatius Loyola prägen auch im starken Maße das Gefüge der Ode IV. 12, darüber hinaus erweisen sich als genauso wichtige Kontexte das Topos von Theatrum mundi und das literarische Werk von Horaz (besonders Carm. III. 1). Die Überlegungen münden in der These über die Kohärenz der in seinen theoretischen Schriften erläuterten Ideen mit der Aussage der "späteren" Gedichte von Sarbiewski.

Schlüsselworte: Matthias Kasimir Sarbiewski, Ode, Topos von Theatrum mundi, Jesuitischer Christianismus

Information about Author:

ANNA AL-ARAJ, PhD student at the Faculty of Polish Studies of the Jagiellonian University, graduate in musicology and Polish philology, Jagiellonian University in Cracow; e-mail: annaa.alaraj@gmail.com 